Rizky Yanuarti, Joni Murti Mulyo Aji ${ }^{*}$, Rudi Hartadi

Fakultas Pertanian, Universitas Jember, Jawa Timur

*)Email korespondensi: joni.faperta@unej.ac.id
AGRARIS: Journal of Agribusiness and Rural Develpoment Research

Vol. 5 No. 1 Januari-Juni 2019

\section{Optimalisasi Penggunaan Faktor Produksi Usahatani Jamur Merang di Desa Glagahwero Kecamatan Panti Kabupaten Jember}

\author{
Optimizing the Use of Production Factors of Straw \\ Mushroom Farming in Glagahwero Village, Panti \\ Sub-District, Jember
}

DOI: http://dx.doi.org/10.18196/agr.5170

\begin{abstract}
Glagahwero is one of the largest mushroom producers in Jember, though still lack of production. This research aims to determine factors of production, optimization of production factors, and profit by using optimal production factor. This research was conducted in Glagahwero Village with 32 samples of mushroom farmer. The samples were selected using total sampling method. Data were analyzed using cobb douglas production function to know the factors that significantly influence the production and value of the optimum input use of mushroom farming, and profit analysis to know the comparison of profit value by using the optimum production factor. The results showed that the area of kumbung, seedlings, straw and labor significantly influenced the production of mushroom in Glagahwero but the use of those factors were not optimal (ratio of NPMxi / Pxi> 1), it is necessary to add the amount of production factor use to reach optimal value. The value of profit by using the optimal production factor will be greater than using the actual production
\end{abstract}

factor. The results of this study then become basis in conducting mushroom farming in Glagahwero Village optimally by taking into account the amount of input that use.

Keywords: Cobb Douglas, Optimalization, Profit, Straw Mushroom

\section{INTISARI}

Desa Glagahwero merupakan salah satu penghasil jamur terbesar kedua di Kabupaten Jember, namun masih sering mengalami kekurangan produksi. Penelitian ini dilakukan untuk mengetahui faktor produksi, optimalisasi faktor produksi, dan keuntungan usahatani dengan meggunakan faktor produksi optimal. Penelitian dilaksanakan di Desa Glagahwero dengan 32 sampel petani jamur merang, dipilih menggunakan metode total sampling. Data dianalisis menggunakan analisis fungsi produksi cobb douglas untuk mengetahui faktorfaktor yang secara signifikan mempengaruhi produksi dan nilai penggunaan input optimal usahatani jamur merang, serta analisis keuntungan untuk mengetahui perbandingan nilai keuntungan dengan menggunakan faktor produksi optimal. Hasil penelitian menunjukkan bahwa luas kumbung, bibit, jerami dan tenaga kerja berpengaruh signifikan terhadap produksi jamur merang di Glagahwero namun penggunaanya belum optimal (rasio NPMxi/Pxi>1), diperlukan adanya penambahan tambahan penggunaan faktor produksi untuk mencapai nilai optimal. Nilai keuntungan dengan menggunakan faktor produksi optimal akan lebih besar dibandingkan dengan menggunakan faktor produksi aktual. Hasil penelitian ini kemudian menjadi dasar dalam melaksanakan usahatani jamur merang di Desa Glagahwero secara optimal dengan memerhatikan jumlah input yang digunakaan.

Kata kunci: Cobb Douglas, Jamur merang, Keuntungan, Optimalisasi.

\section{PENDAHULUAN}

Terdapat beberapa jenis jamur yang banyak diminati konsumen dan menjadi jenis jamur unggulan di Indonesia. Jamur merang menempati peringkat pertama untuk jamur yang paling banyak diusahakan oleh petani di Indonesia. Jamur merang mendominasi 55\% - 60\% dari total produksi jamur nasional (Sumarsih, 2010). Pulau jawa, khususnya 
Jawa Timur merupakan salah satu sentra produksi jamur merang di Indonesia. Kabupaten Jember merupakan salah satu kabupaten yang memiliki hasil produksi jamur cukup besar dibandingkan dengan kota lain di Jawa Timur. Terjadi peningkatan permintaan sejalan dengan peningkatan konsumsi jamur merang (Yuliawati, 2016; Saputra, 2014). Namun peningkatan permintaan tersebut belum sepenuhnya dapat dipenuhi. Hal ini disebabkan karena hasil produksi jamur khususnya di Kabupaten Jember mengalami fluktuasi, dimana produksi tertinggi dicapai pada tahun 2012 dengan jumlah 130.047 ton.

Produksi yang fluktuatif dapat disebabkan oleh berbagai macam hal, namun faktor produksi akan memberikan pengaruh langsung terhadap hasil produksi (Maisyaroh, 2013). Media tanam atau susbtrat memberikan pengaruh signifikan terhadap pertumbuhan dan produksi jamur, karena masingmasing media memiliki kadar nutrisi yang berbeda (Luz et al., 2012; Mumpuni et al., 2017). Penelitian terkait media tanam jamur yang memberikan hasil produksi terbaik telah banyak dilakukan, media tanam yang umunya digunakan adalah serabut kelapa, jerami padi dan bahan sisa pertanian lainnya (agricultural waste) (Hoa et al., 2015; Sánchez, 2010; Sukmadi et al., 2002). Faktor produksi lain yang berpengaruh adalah bibit, kapur, gipsum, luas kumbung, tenaga kerja (Maisyaroh, 2013).

Efisiensi penggunaan faktor produksi optimal juga perlu diperhatikan. Penggunaan faktor produksi secara optimal akan mampu memberikan penerimaan atau keuntungan yang maksimal. Umumnya pelaksanaan budidaya jamur belum dilaksanakan secara optimal seperti pada penelitian yang dilakukan oleh Puspitasari (2017) dan Kusumadewi (2012) terhadap budidaya jamur tiram. Hasil penelitian menunjukkan bahwa diperlukan penggunaan faktor produksi yang berimbang untuk mencapai hasil produksi optimum sehingga keuntungan maksimum dapat tercapai.

Penelitian yang telah dilakukan tersebut telah membahas mengenai faktor produksi yang berpengaruh terhadap hasil produksi jamur dan efisiensi penggunaan faktor produksinya. Namun kebanyakan penelitian tersebut dilakukan terhadap jamur tiram, jarang ditemui penelitian serupa terhadap jamur merang. Selain itu dari penelitian yang telah dilakukan belum ditemukan pembahasan mengenai penggabungan faktor produksi dengan optimalisasi penggunaannya pada usahatani jamur merang. Penerapan manajemen penggunaan faktor produksi perlu dilakukan. Dengan menerapkan manajemen penggunaan faktor produksi dan produk yang dihasilkan maka penggunaan faktor produksi optimal dapat dilakukan. Keuntungan dengan menggunakan faktor produksi optimal menghasilkan nilai yang lebih besar dibandingkan dengan penggunaan faktor produksi secara aktual (Kusumadewi, 2012).

Kecamatan Panti merupakan wilayah penghasil jamur terbesar kedua di Kabupaten Jember dengan luas panen 7.200 ha, nilai produktivitas sebesar 1,68 kw/ha, dan total produksi sebesar 12.096 kw. Pada Kecamatan Panti umumnya jenis jamur yang dibudidayakan adalah jamur merang, salah satunya di Desa Glagahwero. Permintaan terhadap jamur merang terus mengalami peningkatan setiap tahunnya. Permintaan tersebut tidak hanya datang dari pasar lokal namun juga dari luar Kabupaten Jember. Kendala yang dialami oleh petani jamur merang di Desa Glagahwero Kecamatan Panti Kabupaten Jember adalah produktivitas rendah dan jumlah produksi jamur merang yang fluktuatif. Jumlah produksi yang fluktuatif ini mengakibatkan hasil produksi jamur merang tidak pasti. Petani jamur merang di Desa Glagahwero lebih sering mengalami kekurangan produksi. Hal ini menyebabkan hasil atau keuntungan yang diterima petani jamur merang kurang maksimal.

Tujuan dari penelitian ini adalah untuk mengetahui faktor-faktor yang mempengaruhi tingkat produksi, alokasi penggunaan faktor-faktor produksi optimal, dan keuntungan yang diterima petani dalam penggunaan faktor produksi secara optimal pada usahatani jamur merang di Desa Glagahwero Kecamatan Panti Kabupaten Jember agar tercapai kegiatan usahatani jamur merang yang optimal dan mampu meningkatkan keuntungan yang diperoleh petani. 


\section{METODE PENELITIAN}

Penelitian ini dilaksanakan pada bulan Desember 2016 hingga Januari 2017 di Desa Glagahwero, pemilihan daerah penelitian menggunakan purposive method. Metode penarikan sampel yang digunakan adalah total sampling yaitu menjadikan seluruh anggota populasi sebagai sampel, dengan jumlah sampel sebanyak 32 orang petani jamur merang di Glagahwero. Metode pengambilan data dilakukan dengan wawancara dengan kuisioner dan studi pustaka. Analisis data yang dilakukan adalah analisis deskriptif, analisis fungsi produksi cobb douglas untuk menganalisis faktor-faktor yang mempengaruhi produksi jamur merang, analisis efisiensi alokatif untuk mengetahui efiensi penggunaan faktor produksi dan menghitung jumlah penggunaan faktor produksi optimal yangn diperlukan (Darwanto, 2010), serta analisis keuntungan untuk mengetahui keuntungan usahatani jamur merang pada kondisi penggunaan faktor produksi actual dan penggunaan faktor produksi optimal, kemudian dibandingkan (Hariyati, 2013). Persamaan fungsi produksi cobb douglas yang digunakan adalah :

$\mathrm{Y}=\mathrm{b} 0 \mathrm{X} 1 \mathrm{~b} 1 \mathrm{X} 2 \mathrm{~b} 2 \mathrm{X} 3 \mathrm{~b} 3 \mathrm{X} 4 \mathrm{~b} 4$

Kemudian dilinierkan menjadi :

$\operatorname{Ln} Y=\ln b 0+b 1 \ln X 1+b 2 \ln X 2+b 3 \ln X 3+b 4 \ln$ $\mathrm{X} 4$ 2)

Y merupakan produksi jamur $(\mathrm{kg}), \mathrm{X} 1$ adalah luas kumbung (m2), X2 adalah jumlah bibit (Ons), X3 adalah jumlah jerami $(\mathrm{Kg}), \mathrm{X} 4$ adalah jumlah tenaga kerja (HKP), b0 adalah Konstanta/Intercept, b1-4 adalah koefisien regresi masing-masing variable bebas. Apabila fungsi cobb-douglas telah dilinierkan maka variabel-variabel pada fungsi tersebut dapat dianalisis menggunakan metode OLS. Pengujian parameter yang digunakan adalah statistik uji $\mathrm{F}$ untuk uji secara serempak, koefisien determinasi (R2) untuk mengetahui jumlah bagian dari variasi total yang dapat diterangkan oleh model, dan uji t untuk uji secara parsial.

\section{HASIL DAN PEMBAHASAN}

\section{FAKTOR-FAKTOR YANG MEMPENGARUHI PRODUKSI JAMUR MERANG}

Hasil dari uji asumsi klasik adalah sebagai berikut Pengujian normalitas data dilakukan dengan melihat hasil dari Normal P-Plot didapatkan hasil bahwa data menyebar disepanjang garis. Berdasarkan hasil tersebut maka dapat dinyatakan data yang digunakan telah berdistribusi normal. Nilai VIF untuk semua variabel bebas berada dibawah 10 dan nilai tolerance lebih besar dari 0,1 hal ini menunjukkan bahwa model terbebas dari gangguan multikolinearitas. Nilai Durbin-Watson berada diantara du dengan (4-du), hal ini menunjukkan bahwa model terbebas dari gangguan autokorelasi. Scatterplot yang didapat menunjukkan bahwa data tidak membentuk pola tertentu. Hal ini menunjukkan bahwa data terbebas dari gangguan heteroskedasitas.

Hasil uji F didapatkan nilai signifikansi 0,000 (nilai probabilitas <0,05), nilai $\mathrm{F}$ hitung 101,788 > nilai $\mathrm{F}$ tabel 2,95. Hal ini menunjukan bahwa variabel terikat (produksi jamur) secara bersama-sama dipengaruhi oleh variabel bebasnya (luas kumbung, bibit, jerami, dan tenaga kerja). Nilai Adj R2 sebesar 0,929, berarti sebesar 92,9 persen keragaman dari variabel terikat dapat dijelaskan oleh keragaman variabel bebas di dalam model, sedangkan sisanya sebesar 7,1 persen dijelaskan oleh keragaman variabel lain di luar model. Hasil pengujian disajikan pada Tabel 1.

\section{TABEL 1. HASIL ANALISIS REGRESI FUNGSI PRODUKSI COBB DOUGLAS}

\begin{tabular}{|c|c|c|c|c|}
\hline Variabel Bebas & Koef.Regresi & Std. Error & thitung & Signifikansi \\
\hline Luas Kumbung & 0,526 & 0,145 & $3,618^{* * *}$ & 0,001 \\
\hline Bibit & 0,161 & 0,093 & $1,730^{*}$ & 0,095 \\
\hline Jerami & 0,247 & 0,140 & $1,763^{*}$ & 0,089 \\
\hline Tenaga Kerja & 0,297 & 0,154 & $1,925^{*}$ & 0,065 \\
\hline Konstanta & \multicolumn{4}{|c|}{$-1,000($ Anti $\ln =0,368)$} \\
\hline t tabel $(\alpha=0,05)$ & \multicolumn{4}{|l|}{2,048} \\
\hline t tabel $(\alpha=0,1)$ & \multicolumn{4}{|l|}{ 1,701 } \\
\hline \multicolumn{5}{|c|}{ Sumber: Analisis data primer, 2017} \\
\hline \multicolumn{5}{|c|}{ Keterangan : ${ }^{* * *}$ signifikan pada taraf kepercayaan $99 \%$} \\
\hline
\end{tabular}

Variabel luas kumbung secara signifikan mempengaruhi produksi jamur merang dengan taraf kepercayaan 99\%. Koefisien regresi bernilai positif, hal ini dapat diartikan bahwa terdapat hubungan 
positif antara luas kumbung dengan produksi jamur merang. Dimana dengan asumsi ceteris paribus setiap penambahan $1 \%$ input luas kumbung akan menambah produksi jamur merang sebesar $0,526 \%$. Hal ini sesuai dengan penelitian Priyatno (2002) yang menyatakan bahwa terdapat hubungan positif antara luas kumbung yang dimiliki oleh petani dengan jumlah produksi jamur merang yang diperoleh. Hubungan positif ini diinterpretasikan bahwa semakin besar luasan kumbung yang dimiliki, hal ini berarti luas tanam jamur merang semakin besar, sehingga secara langsung akan berpengaruh terhadap meningkatnya hasil produksi yang diperoleh.

Variabel bibit secara signifikan berpengaruh produksi jamur merang dengan taraf kepercayaan $90 \%$. Koefisien regresi bernilai positif, hal ini dapat diartikan bahwa terdapat hubungan positif antara bibit dengan produksi jamur merang. Dimana dengan asumsi (ceteris paribus) setiap penambahan 1\% bibit, akan meningkatkan produksi sebesar $0,161 \%$. Hal ini sesuai dengan pendapat Maisyaroh (2013) yang menyatakan bahwa antara jumlah penggunaan bibit dengan produksi memiliki hubungan yang signifikan, dan hubungannya cenderung postif. Sejalan dengan hal tersebut, Saikia et al. (2013) penambahan bibit dalam jumlah tertentu akan meningkatkan produktivitas jamur. Hal ini diinterpretasikan bahwa semakin banyak jumlah bibit yang digunakan, maka pertumbuhan miselia jamur akan semakin cepat, dimana dapat menekan pertumbuhan kontaminan jamur dan berpengaruh positif terhadap hasil produksi jamur yang akan semakin meningkat.

$$
\text { Variabel jerami secara signifikan }
$$

mempengaruhi produksi jamur merang dengan taraf kepercayaan 90\%. Koefisien regresi bernilai positif, hal ini dapat diartikan bahwa terdapat hubungan positif antara jumlah penggunaan jerami dengan produksi jamur merang. Dimana dengan asumsi (ceteris paribus) setiap penambahan 1\% jerami maka akan meningkatkan produksi jamur merang sebesar 0,247\%. Hal ini sesuai dengan pendapat Maisyaroh (2013) yang menyatakan bahwa jumlah penggunaan serbuk kayu sebagai media tanam berpengaruh signifikan terhadap produksi. Hubungan yang didapat adalah hubungan positif, dimana semakin banyak jumlah media tanam yang digunakan maka jamur akan memiliki ruang tumbuh semakin luas, hal ini akan berpengaruh terhadap peningkatan produksi jamur.

Variabel tenaga kerja signifikan berpengaruh produksi jamur merang dengan taraf kepercayaan 90\%. Koefisien regresi bernilai positif, hal ini dapat diartikan bahwa terdapat hubungan positif antara tenaga kerja dengan produksi jamur merang. Dimana dengan asumsi (ceteris paribus) setiap penambahan 1\% tenaga kerja maka akan meningkatkan produksi jamur merang sebesar 0,297\%. Hal ini sesuai dengan pendapat Mandei (2011) dan Saikia et al. (2013) yang menyatakan bahwa tenaga kerja memiliki pengaruh yang signifikan terhadap produksi. Penambahan tenaga kerja selama tidak melebihi penggunaan tenaga kerja maksimum, akan mampu meningkatkan produksi, karena pengerjian setiap proses budidaya menjadi lebih cepat dan lancar.

\section{OPTIMALISASI FAKTOR PRODUKSI JAMUR MERANG}

Rasio NPMxi dengan Pxi masing-masing faktor produksi yang digunakan pada usahatani jamur merang disajikan pada tabel 2 , dengan tingkat ratarata produksi jamur merang $573,72 \mathrm{~kg}$ dan harga ratarata hasil produksi jamur merang adalah $14.781,25 / \mathrm{kg}$.

TABEL 2. PERBANDINGAN NILAI NPMXI DENGAN PXI PADA FAKTOR PRODUKSI USAHATANI JAMUR MERANG DI DESA GLAGAHWERO

\begin{tabular}{|c|c|c|c|c|c|c|c|}
\hline No & Nama Variabel & $\mathrm{Bi}$ & Xi & Pxi & NPMxi & $\begin{array}{l}\text { NPMxi } \\
\text { /Pxi }\end{array}$ & thitung \\
\hline 1 & Luas Kumbung $\left(m^{2}\right)$ & 0,526 & 190,61 & $6.556,95$ & $23.401,65$ & 3,57 & $20,450^{*}$ \\
\hline 2 & Bibit (ons) & 0,161 & 187,89 & $2.400,00$ & $7.266,63$ & 3,03 & $14,896^{*}$ \\
\hline 3 & Jerami (kg) & 0,247 & $14.449,22$ & 101,95 & 144,97 & 1,42 & $5,899^{*}$ \\
\hline 4 & Tenaga Kerja (HKP) & 0,297 & 94,79 & $8.599,21$ & $26.570,84$ & 3,09 & $8,673^{*}$ \\
\hline & $\begin{array}{l}(\alpha=0,05) \quad 2,0 \\
\operatorname{gan}\left({ }^{*}\right) \text { signifikan }\end{array}$ & 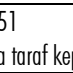 & cataan $95 \%$ & & & & \\
\hline
\end{tabular}

Berdasarkan hasil analisis tersebut dapat diketahui bahwa rasioantara NPMxi dengan Pxi bagi seluruh variabel bernilai lebih dari 1 . Hal ini berarti bahwa penggunaan faktor produksi jamur merang di Desa Glagahwero belum efisien. Efisiensi dicapai dengan menambah penggunaan faktor produksi. 
Sesuai dengan pendapatan Puspitasari (2017) yang menyatakan bahwa usahtani jamur di Kabupaten Semarang belum efisien dalam penggunaan faktor produksinya, dengan rasio antara nilai produk marginal dan harga masing-masing faktor produksi masih lebih dari satu. Maka penggunaan faktor poduksi pelu ditambah agar efisiensi alokatif tercapai, dimana rasio antara nilai produk marginal sama dengan harga masing-masing faktor produksinya.

Berikut adalah hasil analisis optimalisasi dengan nilai rasio NPMxi dan Pxi dimana dari hasil analisis faktor produksi optimal menunjukan perlunya penambahan input luas kumbung, bibit, jerami, dan tenaga kerja untuk mencapai titik optimum.

\section{TABEL 3. PENGGUNAAN FAKTOR PRODUKSI OPTIMAL PADA USAHATANI} JAMUR MERANG DI DESA GLAGAHWERO TAHUN 2017

\begin{tabular}{llrrrrr}
\hline No & $\begin{array}{c}\text { Nama } \\
\text { Variabel }\end{array}$ & Satuan & Xi (aktual) & Xi (Optimal) & Perubahan & $\begin{array}{r}\text { Persentase } \\
\text { Perubahan }\end{array}$ \\
\hline 1 & Luas Kumbung & $\mathrm{m}^{2}$ & 190,61 & 680,29 & 489,68 & 256,90 \\
2 & Bibit & ons & 187,89 & 568,89 & 381,00 & 202,78 \\
3 & Jerami & $\mathrm{kg}$ & $14.449,22$ & $20.545,91$ & $6.096,69$ & 42,19 \\
4 & Tenaga Kerja & HKP & 94,79 & 292,89 & 198,10 & 208,99 \\
\hline
\end{tabular}

Sumber : Data primer diolah, 2017

Berdasarkan tabel 3, untuk mencapai alokasi penggunaan input yang optimal maka perlu adanya penambahan dalam penggunaan faktor produksi jamur merang di Desa Glagahwero. Hasil perhitungan rasio NPMxi dengan Pxi keseluruhan faktor produksi menunjukkan nilai lebih dari satu, sehingga faktor produksi luas kumbung, bibit, jerami, dan tenaga kerja perlu ditambah penggunaannya. Nilai penggunaan faktor produksi optimal yang terdapat pada tabel 3 merupakan nilai penggunaan untuk satu kali siklus produksi. Satu siklus produksi usahatani jamur merang di Desa Glagahwero berlangsung selama 45 hari.

\section{KEUNTUNGAN PADA PENGGUNAAN FAKTOR PRODUKSI OPTIMAL}

Alokasi penggunaan faktor produksi secara optimal akan mempengaruhi nilai keuntungan yang diperoleh oleh petani. Nilai yang akan disampaikan pada pembahasan berikut merupakan nilai rata-rata dari penggunaan faktor produksi, harga faktor produksi, hasil produksi, harga hasil produksi dari 32 responden petani jamur merang di Desa Glagahwero selama satu siklus produksi jamur merang, yaitu selama 45 hari. Berikut ini merupakan ringkasan hasil perhitungan keuntungan pada usahtani jamur merang dengan menggunakan faktor produksi aktuan dan optimal.

\section{TABEL 4. ANALLSIS KEUNTUNGAN USAHATANI JAMUR MERANG DI DESA GLAGAHWERO KECAMATAN PANTI KABUPATEN JEMBER TAHUN 2017}

\begin{tabular}{clrr}
\hline \multirow{2}{*}{ No } & \multirow{2}{*}{ Keterangan } & \multicolumn{2}{c}{ Jumlah (Rp) } \\
\cline { 3 - 4 } & & \multicolumn{1}{c}{ Aktual } & \multicolumn{1}{c}{ Optimal } \\
\hline 1. & Biaya Tetap & $1.538 .089,83$ & $4.748 .901,41$ \\
2. & Biaya Variabel & $3.007 .893,75$ & $6.247 .374,74$ \\
3. & Total Biaya & $4.545 .983,58$ & $10.996 .276,15$ \\
\hline 4. & Jumlah Produksi $(\mathrm{kg})$ & 573,72 & $1.982,07$ \\
5. & Penerimaan & $8.604 .317,71$ & 29.297 .485 \\
\hline 6. & Keuntungan & $4.058 .334,13$ & $18.301 .208,85$ \\
\hline
\end{tabular}

Sumber : Data primer diolah, 2017

Berdasarkan tabel 4 diketahui bahwa besarnya produksi selama satu siklus produksi (45 hari) pada kondisi aktual dan optimal yaitu sebesar $573,72 \mathrm{~kg}$ dan $1.982,07 \mathrm{~kg}$. Keuntungan diperoleh dengan mengurangkan total peneriman dan total biaya, nilai keuntungan masing-masing yang diperoleh adalah sebesar Rp 4.058.334,13 dan Rp 18.301.208,85. Hasil produksi pada penggunaan input optimal diperoleh dengan memasukkan nilai masing-masing penggunaan input ke dalam fungsi cob douglass yang telah diperoleh. Terjadi peningkatan hasil produksi pada saat penggunaan input optimal, hal ini berarti produktivitas mengalami peningkatan. Hal ini sesuai dengan pendapat Pamoriana (2013) yang menyatakan bahwa peningkatan produktivitas akan secara langsung berdampak pada meningkatnya hasil produksi usahatani.

Total biaya yang dikeluarkan jauh lebih besar dibandingkan pada penggunaan input aktual, namun keuntungan pada penggunaan input optimal juga jauh lebih besar bila dibandingkan dengan keuntungan pada penggunaan input aktual. Hal ini sesuai dengan pendapat Saputra (2016) yang menyatakan bahwa dengan menerapkan manajemen faktor produksi dan menggunakan kombinasi faktor produksi optimal maka keuntungan usahtani jamur dapat ditingkatkan. Keuntungan yang diperoleh lebih besar dibandingkan 
AGRARIS: Journal of Agribusiness

and Rural Development Research

dengan menggunakan faktor produksi aktual yang belum efisien.

\section{KESIMPULAN}

Variabel luas kumbung (X1), bibit (X2), jerami (X3), dan tenaga kerja (X4) mempengaruhi produksi jamur merang dan memberikan pengaruh yang positif terhadap produksi jamur merang di Desa Glagahwero. Petani belum menggunakan faktor-faktor produksi jamur merang di Desa Glagahwero secara optimal. Hal ini diketahui dengan melihat nilai rasio antara NPMxi dan Pxi lebih dari satu. Petani jamur merang di Desa Glagahwero memperoleh keuntungan dengan menggunakan faktor produksi pada kondisi optimal sebesar Rp 18.301.208,85 lebih besar dari keuntungan yang diperoleh dalam penggunaan faktor produksi pada kondisi aktual sebesar $\mathrm{Rp}$ 4.058.334,13.

\section{DAFTAR PUSTAKA}

Darwanto. (2010). Analisis Efisiensi Usahatani Padi di Jawa Tengah (Penerapan Analisis Frontier). Organisasi dan Manajemen. 6(1) : 46-57. jurnal.ut.ac.id/index. php/JOM/article/downloa $d / 282 / 235 /$

Hariyati Y. (2013). Analisis Usahatani Kakao Rakyat di Berbagai Pola Tanam Tumpang Sari. Agribisnis Indonesia. 1(2): 155-166. journal. ipb.ac.id/index.php/jagbi/article/view/8849

Hoa HT., Wang CL., Wang CH. (2015). The Effects of Different Substrates on the Growth, Yield, and Nutritional Composition of Two Oyster Mushrooms (Pleurotus ostreatus and Pleurotus cystidiosus). Mycobiology. 43( 4): 423-434. www.ncbi.nlm.nih.gov/pmc/article s/PMC4731647/

Kusumadewi E. (2012). Optimalisasi Produksi Jamur Tiram Putih di Pusat Pelatihan Pertanian dan Pedesaan Swadaya (P4S) Nusa Indah Bogor. Institut Pertanian Bogor. Retrieved from http://repository.ipb.ac.id/handle/123456789 $/ 56145$

Luz JMR., Nunes MD., Paes SA., Torres DP., Silva MCS., Kasuya MCM. (2012). Lignocellulolytic Enzyme Production of Pleurotus Ostreatus Growth in Agroindustrial Wastes. Braz. J. Microbiol. 43 : 1508-1515. www.scielo.br/ scielo.php? script $=$ sci_arttext\&pid $=$ S1517$8382201200040003 \overline{5}$

Maisyaroh DS. (2013). Analisis Usahatani Jamur Tiram di Kabupaten Deli Serdang. Social Economic Of Agriculture And Agribusiness. 2(2) : 1-15. https://jurnal.usu.ac.id/index.php/ceress/articl e/view/6945

Mandei JR., Pangemanan L., Tangkere EG., Wongkar N. (2011). Efisiensi Penggunaan Faktor Produksi Usahatani Cabe di Kelurahan Marawas Kecamatan Tondano Utara Kabupaten Minahasa. ASE. 7(3) : 58-68. https://ejournal. unsrat.ac.id/index.php/jisep/article/view/7354

Mumpuni A., Ekowati N., Purnomowati, Purwati ES. (2017). Growth and Protein Content Establishment of Pleurotus ostreatuson Liquid and Solid Medium. Biosaintifika. 9(3) : 572-578. journal.unnes.ac.id/nju/index.php/b iosaintifika/article/view/11660

Pamoriana W. (2013). Anlisis Produktivitas Tanaman Kopi di Kecamatan Gemawang Kabupaten Temanggung. Economic Development Analysis Journal, 2(1): 1-9. https://journal. unnes.ac.id/artikel_sju/edaj/1006

Priyatno E. (2002). Skala produksi pada usatani jamur merang musim tanam tahun 2002 di Kecamatan Wuluhan Kabupaten Jember. Skripsi. Jember : Universitas Jember. Repo sitory.unej.ac.id/handle/123456789/68947

Puspitasari VD. (2017). Analisis Efisinsi Ekonomi Penggunaan Faktor-Faktor Produksi Pada Usahatani Jamur Tiram di Desa Genting Kecamatn Jambu Kabupaten Semarang. Agrisocionomics 1(1): 1-18.https://ejournal2. undip.ac.id/index.php/agrisocionomics/article /view/1645

Sánchez C. 2010. Cultivation of Pleurotus ostreatus and Other Edible Mushrooms. Appl Microbiol Biotechnol. 85: 1321-1337.www. ncbi.nlm.nih.gov/pubmed/19956947

Saikia T., Hazarika JP., Gogoi H. (2013). Resource Use Efficiency in Mushroom Cultivation in Jorhat District of Assam. Agriculture Update. 9(1) : 37-40.www.researchjournal.co.in/upload/ass ignments/9 37-40.pdf

Saputra, AS., Triana DH., Jani J. (2016). Analisis Efisiensi Biaya Usahatani Jamur Tiram (Pleurotus Sp) dan Pemasarannya di Kabupaten Jember. Agritop 1(2): 195-206. digilib.unmuhjember.ac.id/download.php?id $=2391$

Sukmadi H., Hidayat N., Lestari ER. (2002). Optimasi Produksi Jamur Tiram Abu-abu (Pleurotus sajorcaju)Pada Campuran Serat Garut dan Jerami Padi. Teknologi Pertanian. 4 (1): 1 12. http://jtp.ub.ac.id/index.php/jtp/article/vi ew/146

Sumarsih S. 2010. Untung Besar Usaha Bibit Jamur Tiram. Bogor: Penebar Swadaya. 